\title{
Ocean acidification has no effect on thermal bleaching in the coral Seriatopora caliendrum
}

Article in Coral Reefs · March 2014

DOI: $10.1007 /$ s00338-013-1085-2

CITATIONS

12

3 authors, including:

\section{Chris Wall}

University of Hawai'i at Mānoa

11 PUBLICATIONS 71 CITATIONS

SEE PROFILE
READS

96
Tung-Yung Fan

National Museum of Marine Biology and Aqu... 58 PUBLICATIONS 864 CITATIONS

SEE PROFILE 


\title{
Ocean acidification has no effect on thermal bleaching in the coral Seriatopora caliendrum
}

\author{
C. B. Wall $\cdot$ T.-Y. Fan $\cdot$ P. J. Edmunds
}

Received: 3 May 2013/ Accepted: 21 September 2013

(c) Springer-Verlag Berlin Heidelberg 2013

\begin{abstract}
The objective of this study was to test whether elevated $\mathrm{pCO}_{2}$ predicted for the year $2100(85.1 \mathrm{~Pa})$ affects bleaching in the coral Seriatopora caliendrum (Ehrenberg 1834) either independently or interactively with high temperature $\left(30.5^{\circ} \mathrm{C}\right)$. Response variables detected the sequence of events associated with the onset of bleaching: reduction in the photosynthetic performance of symbionts as measured by maximum photochemical efficiency $\left(F_{\mathrm{v}} / F_{\mathrm{m}}\right)$ and effective photochemical efficiency $\left(\Delta F / F_{\mathrm{m}}{ }^{\prime}\right)$ of PSII, declines in net photosynthesis $\left(P^{\text {net }}\right)$ and photosynthetic efficiency (alpha, $\alpha$ ), and finally, reduced chlorophyll $a$ and symbiont concentrations. S. caliendrum was collected from Nanwan Bay, Taiwan, and subjected to combinations of temperature $\left(27.7\right.$ vs. $\left.30.5^{\circ} \mathrm{C}\right)$ and $\mathrm{pCO}_{2}$ (45.1 vs. $85.1 \mathrm{~Pa}$ ) for 14 days. High temperature reduced values of all dependent variables (i.e., bleaching occurred), but high $\mathrm{pCO}_{2}$ did not affect Symbiodinium photophysiology or productivity, and did not cause bleaching. These results suggest that short-term exposure to $81.5 \mathrm{~Pa} \mathrm{pCO}_{2}$,
\end{abstract}

Communicated by Biology Editor Dr. Anastazia Banaszak

C. B. Wall $(\bowtie) \cdot$ P. J. Edmunds

Department of Biology, California State University,

18111 Nordhoff Street, Northridge, CA 91330-8303, USA

e-mail: cbw0047@gmail.com

C. B. Wall

College of Life-Sciences, Santa Monica College,

1900 Pico Boulevard, Santa Monica, CA 90405-1628, USA

T.-Y. Fan

National Museum of Marine Biology and Aquarium, Taiwan, Republic of China

T.-Y. Fan

Institute of Marine Biodiversity and Evolution, National Dong

Hwa University, Taiwan, Republic of China alone and in combination with elevated temperature, does not cause or affect coral bleaching.

Keywords Ocean acidification - Temperature . Bleaching · Scleractinia $\cdot$ Taiwan

\section{Introduction}

Increased atmospheric $\mathrm{CO}_{2}$ from anthropogenic activities is contributing to global climate change (GCC) and threatens coral reefs through seawater warming and ocean acidification (OA) (Hoegh-Guldberg et al. 2007). OA caused by the dissolution of $\mathrm{CO}_{2}$ in seawater results in a decrease in ocean $\mathrm{pH}$ and a shift in the carbonate chemistry of seawater that is unfavorable for the deposition of calcium carbonate (Chan and Connolly 2013). During the twentieth century, rising atmospheric $\mathrm{CO}_{2}$ has resulted in a $0.7{ }^{\circ} \mathrm{C}$ increase in mean sea surface temperatures (SST) and a decrease in sea surface $\mathrm{pH}_{\mathrm{T}}$ of 0.1 (Caldiera et al. 2003; Raven 2005). Atmospheric $\mathrm{CO}_{2}$ is projected to increase from current levels $(\sim 39.0 \mathrm{~Pa})$ to between 49.6 and $86.1 \mathrm{~Pa}$ by the end of this century (van Vuuren et al. 2011) and likely will increase SST $2-3{ }^{\circ} \mathrm{C}$ and reduce sea surface $\mathrm{pH}_{\mathrm{T}}$ by 0.3 (Meehl et al. 2007). As a result, GCC will increase the incidence of warm-water coral bleaching, and reef accretion will slow due to elevated SST and OA (Pandolfi et al. 2011).

Rising SST has contributed to the decline in abundance of corals (Hoegh-Guldberg 1999; Pandolfi et al. 2011), largely through bleaching (Loya et al. 2001). Paling of coral tissue (i.e., "bleaching"), occurs in response to multiple environmental stressors (Glynn 1996; Fitt et al. 2001), of which high light intensities and elevated temperature are most prominent in causing large-scale 
bleaching (Fitt et al. 2001). Coral bleaching progresses through a series of cellular events culminating in the reduction in the concentrations of photopigments and densities of Symbiodinium spp. algae within the coral, and in some instances, results in death (Glynn 1983; Fitt et al. 2001). Photoinhibition from oxidative damage to the photosynthetic apparatus of Symbiodinium, particularly the D1-protein, and impaired carbon fixation initiates the events leading to symbiont expulsion (Lesser 1997; Jones et al. 1998; Warner et al. 1999; Smith et al. 2005). These effects can first be detected as reductions in the quantum yield of photosystem II (PSII) (hereafter, photochemical efficiency) in response to PSII photoinactivation (Warner et al. 2010), and a reduced capacity to use light energy together with reducing agents to fix $\mathrm{CO}_{2}$ in the Calvin cycle (hereafter, photosynthetic capacity) (Iglesias-Prieto et al. 1992; Jones et al. 1998; Warner et al. 1999). As these effects persist, impairment of the light and dark reactions of photosynthesis and damage to the photosynthetic apparatus by reactive oxygen species (Lesser 1997; Jones et al. 1998; Smith et al. 2005) leads to the expulsion of Symbiodinium, host cell detachment (Gates et al. 1992), or apoptosis (Dunn et al. 2007).

The effects of OA on biomineralization have received considerable attention (Chan and Connolly 2013), but the effects on photosynthesis of Symbiodinium within corals remain unclear. Hermatypic corals depend on Symbiodinium to provide photosynthetically fixed carbon to fuel metabolism (Muscatine et al. 1984). Some studies with corals suggest OA reduces net photosynthesis $\left(P^{\text {net }}\right)$ (Reynaud et al. 2003; Anthony et al. 2008), and the maximum rate of photosynthesis (i.e., $P_{\max }^{\text {net }}$ ) (Crawley et al. 2010), although some corals show no response of photosynthesis to $\mathrm{pCO}_{2}$ enrichment (Leclercq et al. 2002; Godinot et al. 2011). OA has also been reported to induce bleaching in at least two corals, both alone and in concert with elevated temperature (Anthony et al. 2008). Anthony et al. (2008) hypothesized that the mechanism of OAinduced bleaching involved the disruption of carbon-concentration mechanisms used by Symbiodinium (Weis et al. 1989; Leggat et al. 1999), or impaired photoprotective mechanisms, such as photorespiration (Crawley et al. 2010) and nonphotochemical quenching (Hill et al. 2005). Support for these hypotheses is limited; however, as effects of OA on the photophysiology of Symbiodinium in hospite have not been studied in detail, and where these effects have been investigated, the outcomes are equivocal (Godinot et al. 2011; Iguchi et al. 2011; Edmunds 2012) and may be specific to Symbiodinium phylotypes (Brading et al. 2011).

The objective of the study was to test whether elevated $\mathrm{pCO}_{2}$ affects bleaching in corals. An experiment was conducted in which corals were exposed to two temperatures and two $\mathrm{pCO}_{2}$ regimes, with the effects assessed using dependent variables that detect the early stages of bleaching (after Fitt et al. 2001): (1) the onset of reduced photochemical efficiency (2) intermediate effects manifesting in reduced photosynthetic capacity and efficiency prior to visible paling of tissue, and (3) terminal effects culminating in reduced Symbiodinium and photopigment densities. The experiment was conducted with the branching pocilloporid coral Seriatopora caliendrum (Ehrenberg 1834) that is common on the shallow reefs of southern Taiwan (Dai and Horng 2009) where this study was conducted and has previously been reported susceptible to thermal bleaching (Loya et al. 2001).

\section{Materials and methods}

\section{Experimental design}

Four treatments contrasted ambient temperature-ambient $\mathrm{pCO}_{2} \quad\left(\mathrm{AT}-\mathrm{ACO}_{2}\right)$, ambient temperature-high $\mathrm{pCO}_{2}$ (AT- $\left.\mathrm{HCO}_{2}\right)$, high temperature-ambient $\mathrm{pCO}_{2}\left(\mathrm{HT}-\mathrm{ACO}_{2}\right)$, and high temperature-high $\mathrm{pCO}_{2}\left(\mathrm{HT}-\mathrm{HCO}_{2}\right)$. Ambient temperature referred to the seawater on shallow reefs in Nanwan Bay when the experiment was conducted in July and August $2011\left(28.0 \pm 0.2{ }^{\circ} \mathrm{C}\right.$ at $3 \mathrm{~m}$ depth [mean $\pm \mathrm{SE}$, $n=21$ days]) and therefore was set at $27.5^{\circ} \mathrm{C}$. Ambient $\mathrm{pCO}_{2}$ reflected ambient $\mathrm{CO}_{2}$ conditions, although this routinely was above the global mean atmospheric value of $\sim 39.0 \mathrm{~Pa}$. High temperature was relative to the maximum seawater temperature recorded at $3 \mathrm{~m}$ depth on the study reef in summer $\left(31.0^{\circ} \mathrm{C}\right)$ (T-Y Fan pers comm) and was $30.5{ }^{\circ} \mathrm{C}$. High $\mathrm{pCO}_{2}$ represented conditions projected to occur by the year $2100(\sim 86 \mathrm{~Pa})$ under the high $\mathrm{CO}_{2}$ emission scenario RCP 6.0 (van Vuuren et al. 2011).

We hypothesized that OA would cause bleaching as defined by decreased photochemical efficiency, reduced photosynthetic capacity and efficiency, depressed chlorophyll $a$ content, and lowered Symbiodinium densities and that these effects would be exacerbated with high temperature. To test this hypothesis, corals were exposed to treatments in 8 tanks $\left(n=2\right.$ tanks treatment $\left.{ }^{-1}\right)$ filled with $130 \mathrm{~L}$ of filtered $(1.0 \mu \mathrm{m})$ seawater. Treatments were maintained at a salinity of 33.4 (measured with a YSI 3100 Conductivity Meter, YSI Inc., USA) with $20 \%$ water changes each evening. Temperatures were maintained independently by microsensor-based regulators (AquaController, Neptune Systems, USA) connected to a 300-W heater (Taikong Corp.), and chiller (Aquatek, Aquasystems, Taiwan), and the seawater was mixed with a pump $\left(1,451 \mathrm{~L} \mathrm{~h}^{-1}\right)$. Light was provided to each tank by two 
18-W fluorescent bulbs (TL-D Blue, Phillips, USA) and two 150-W metal-halide bulbs on a $12 \mathrm{~h}$ light: $12 \mathrm{~h}$ dark cycle that created mean irradiances ranging from 251 to $279 \mu \mathrm{mol}$ photons $\mathrm{m}^{-2} \mathrm{~s}^{-1}$ as measured beneath the seawater using a spherical light sensor (LI-193, Li-Cor, USA).

Treatments of $\mathrm{pCO}_{2}$ were maintained by bubbling ambient air $\left(\mathrm{A}-\mathrm{CO}_{2}\right)$ or $\mathrm{CO}_{2}$-enriched air into the tanks $\left(\mathrm{H}-\mathrm{CO}_{2}\right)$. To prepare high $\mathrm{pCO}_{2}$ treatments, $\mathrm{CO}_{2}$ was mixed with ambient air by solenoid-controlled gas mixing technology (Model A352, Qubit Systems, Canada). $\mathrm{CO}_{2}$ and ambient air were mixed in a chamber, and the $\mathrm{pCO}_{2}$ measured using an infrared (IR) gas analyzer (S151, Qubit Systems) calibrated against certified reference gas (1,793 ppm $\mathrm{CO}_{2}$, San Ying Gas Co., Taiwan). The $\mathrm{pCO}_{2}$ treatments were maintained dynamically by the IR gas analyzer, which regulated a solenoid valve controlling the flow of $\mathrm{CO}_{2}$ gas. The final $\mathrm{pCO}_{2}$ was logged in ppm on a PC using LabPro software (Vernier Software and Technology, USA), and a pump delivered the gas mixture to the high-pCO $\mathrm{PO}_{2}$ tanks at $\sim 15 \mathrm{~L} \mathrm{~min}^{-1}$. Ambient $\mathrm{pCO}_{2}$ tanks received ambient, non- $\mathrm{CO}_{2}$-enriched air at a similar flow rate.

Treatments were monitored daily at 0900, 1200, and $1700 \mathrm{hrs}$ for temperature and salinity; irradiance was measured at $1200 \mathrm{hrs}$; $\mathrm{pH}$ and carbonate chemistry of the treatments were determined daily on seawater samples ( $\sim 250 \mathrm{~mL}$ ) taken from all tanks at $0900 \mathrm{hrs}$. Temperature was measured using a certified digital thermometer (Fisher Scientific 15-077-8, $\pm 0.05{ }^{\circ} \mathrm{C}$ ), and seawater was assessed for total alkalinity (TA, $\mu \mathrm{mol} \mathrm{kg}{ }^{-1}$ ) and $\mathrm{pCO}_{2}$ by potentiometric titrations following standard operating procedures (SOP) 3 (Dickson et al. 2007); $\mathrm{pH}_{\mathrm{T}}$ was determined spectrophotometrically using $m$-cresol purple (SOP 6B, Dickson et al. 2007). Seawater samples were titrated using an open-cell autotitrator (Model DL50, MettlerToledo, USA) filled with certified acid titrant (from A. Dickson, Scripps Institution of Oceanography) and equipped with a DG115-SC pH probe (Mettler-Toledo). TA was evaluated for precision and accuracy using certified reference materials (CRM) of known TA (from A. Dickson, Scripps Institution of Oceanography) with our analyses differing $<0.9 \%$ from certified values. $\mathrm{pH}_{\mathrm{T}}$, salinity, temperature, and TA were used in CO2SYS software in Microsoft Excel (Fangue et al. 2010) to calculate the components of the dissolved inorganic carbon (DIC) system in seawater.

\section{Coral collection}

Sixty juvenile $S$. caliendrum ( $<4 \mathrm{~cm}$ diam.) were collected on July 22, 2011, from Hobihu Reef $\left(21^{\circ} 56.799^{\prime} \mathrm{N}\right.$, $120^{\circ} 44.968^{\prime} \mathrm{E}$ ), Nanwan Bay. Colonies were collected from 3 to $4 \mathrm{~m}$ depth and transported to a flow-through aquarium at the National Museum of Marine Biology and Aquarium (NMMBA) where they were allowed to recover from collection for $24 \mathrm{~h}$. The recovery tank was filled with flowing, filtered seawater $(50 \mu \mathrm{m})$ and mixed with a pump $\left(1,451 \mathrm{~L} \mathrm{~h}^{-1}\right)$. Temperature was maintained at ambient conditions $\left(28.07 \pm 0.10{ }^{\circ} \mathrm{C}, \pm \mathrm{SE}, n=24\right)$ and light was supplied at $164 \pm 4 \mu \mathrm{mol}$ photons $\mathrm{m}^{-2} \mathrm{~s}^{-1}$ on a $12 \mathrm{~h}$ light: 12 h dark cycle.

One day following collection, the colonies of $S$. caliendrum were suspended in the recovery tank using nylon line and left to recover for 5 days. On July 28, 2011, they were placed randomly into the treatment tanks ( $n=7 \operatorname{tank}^{-1}$ ) for incubations lasting 14 days. On August 11, 2011, corals were processed over 3 days for the dependent variables described below and retained in experimental conditions during this time. To maintain comparable exposure periods among like-temperature treatments, corals from the HT treatments were processed first, followed by corals in the AT treatments, with corals randomly selected for processing within each temperature treatments.

\section{Photochemical efficiency}

The effects of temperature and $\mathrm{pCO}_{2}$ on photochemical efficiency were tested by measuring the maximum photochemical efficiency of open RCIIs in the dark $\left(F_{\mathrm{v}} / F_{\mathrm{m}}\right)$ and the effective photochemical efficiency of RCII in the light $\left(\Delta F / F_{\mathrm{m}}{ }^{\prime}\right)$ using pulse amplitude modulation (PAM) fluorometry. PAM fluorometry is an effective tool to assess noninvasively the photophysiology of Symbiodinium in hospite (Warner et al. 1996, 2010) and provides an indication of PSII photochemical activity and the transport of electrons through PSII (Cosgrove and Borowitzka 2010). $F_{\mathrm{v}} / F_{\mathrm{m}}$ provides a measure of photochemical quenching $(q \mathrm{P})$ reflecting the rate of charge separation across PSII in the open (i.e., dark-adapted) state, while $\Delta F / F_{\mathrm{m}}{ }^{\prime}$ accounts for photochemical and nonphotochemical quenching (NPQ), including mechanisms for the dissipation of excess absorbed light energy as heat through the PSII antennae complex (Hill et al. 2005). NPQ is of particular biological importance as a mechanism of photoprotection and avoidance of photoinhibition under peak daily irradiance and under conditions causing bleaching (Warner et al. 1996; Jones et al. 1998; Hoegh-Guldberg and Jones 1999).

Photochemical efficiency was assessed using a DivingPAM (Waltz, GmbH, Effeltrich, Germany) operated at a gain of 6 , intensity of 9 , and a slit width of 0.8 . Prior to the start of the experiment, PAM settings were adjusted to obtain a range of minimum fluorescence yield $\left(F_{\mathrm{o}}\right)$ between 200 and 400 (arbitrary units) and stabile maximum fluorescence yield $\left(F_{\mathrm{m}}\right) . \Delta F / F_{\mathrm{m}}{ }^{\prime}$ was measured to quantify changes in quantum yield relative to the dark-adapted state 
due to excess thermal energy dissipation and NPQ, and $F_{\mathrm{v}} / F_{\mathrm{m}}$ was measured to quantify the maximum efficiency of open RCIIs in the dark-adapted state. Photochemical efficiency was measured using a 5-mm-diameter fiberoptic probe held $\sim 5 \mathrm{~mm}$ above the tissue and $\sim 1 \mathrm{~cm}$ behind branch tips. $\Delta F / F_{\mathrm{m}}{ }^{\prime}$ was measured under actinic irradiance $\left(\sim 265 \mu \mathrm{mol}\right.$ photons $\left.\mathrm{m}^{-2} \mathrm{~s}^{-1}\right)$ and $F_{\mathrm{v}} / F_{\mathrm{m}}$ under weak indirect red lighting $\left(\leq 2.0 \mu \mathrm{mol}\right.$ photons $\left.\mathrm{m}^{-2} \mathrm{~s}^{-1}\right)$. $\Delta F / F_{\mathrm{m}}{ }^{\prime}$ was measured every second day of the incubation at $1230 \mathrm{hrs}$, and $F_{\mathrm{v}} / F_{\mathrm{m}}$ was measured every second day at $1730 \mathrm{hrs}$. A pilot study was used to determine the duration of dark adaptation necessary to stabilize values of $F_{\mathrm{v}} / F_{\mathrm{m}}$, to identify effects of prolonged darkness on $F_{\mathrm{v}} / F_{\mathrm{m}}$ (i.e., darkinduced reduction in the PQ pool; Hill and Ralph 2008), and to test whether weak indirect red light (as produced from small lamps used during nocturnal PAM measurements) affected $F_{\mathrm{v}} / F_{\mathrm{m}}$. Results indicated $F_{\mathrm{o}}$ stabilized after $<0.5 \mathrm{~h}$ of darkness, and $F_{\mathrm{v}} / F_{\mathrm{m}}$ was statistically indistinguishable when measured following dark adaptation lasting $0.5,1.0$, or $2.0 \mathrm{~h}\left(F_{2,27}=0.137, P=0.872\right)$, or measured with and without weak red light $\left(F_{1,18}=0.352\right.$, $P=0.561)$.

\section{Photosynthesis-irradiance (P/I) curves}

To test for the effects of $\mathrm{pCO}_{2}$ and temperature on the ability for Symbiodinium to utilize light and perform photosynthesis, net photosynthesis $\left(P^{\text {net }}\right)$, determined from changes in $\mathrm{O}_{2}$ concentrations in seawater, was measured under different irradiances using three corals selected randomly from each treatment tank $\left(n=6\right.$ treatment $\left.^{-1}\right)$. Two respirometers were used to measure $P^{\text {net }}$, and each housed a single coral in trials lasting $\sim 1.5-2.0 \mathrm{~h}$. Measurements of $P^{\text {net }}$ began on the 14th day of incubations, and 3 days were required to process all corals in the experiment. Temperatures were maintained by placing the respirometers in a water bath. Water motion in each chamber was provided by a stir-bar, and the flow rate quantified by photographing hydrated Artemia spp. eggs (Sebens and Johnson 1991), revealing the mean flow rate near the center of the respirometer to be $5.43 \pm 0.32 \mathrm{~cm} \mathrm{~s}^{-1}$ ( $\pm \mathrm{SE}$, $n=20$ ). Prior to each trial, corals were maintained in darkness for $1 \mathrm{~h}$ to allow the stimulatory effect of light on respiration to abate (Edmunds and Davies 1988). $\mathrm{O}_{2}$ flux then was measured at ten irradiances supplied in an ascending sequence between 0 and $747 \mu \mathrm{mol}$ photons $\mathrm{m}^{-2} \mathrm{~s}^{-1}$. Light intensities were created by adjusting the height of a 400-W metal-halide lamp (Osram Sylvania, USA) above the respirometer, and measuring the irradiance using a cosine-corrected light sensor recording photosynthetically active radiation (PAR). The light sensor was 1.0 $\mathrm{mm}$ diameter and attached to a Diving-PAM (Waltz, $\mathrm{GmbH}$, Effeltrich, Germany) and was calibrated using a
Li-Cor LI-192 quantum sensor. $\mathrm{O}_{2}$ fluxes were adjusted for changes in $\mathrm{O}_{2}$ concentrations in control chambers filled with seawater alone, and controls were run at each combination of temperature and $\mathrm{pCO}_{2}$ for each irradiance, and during darkness $\left(n=3\right.$ treatment $\left.^{-1}\right)$.

The $\mathrm{O}_{2}$ saturation of seawater was measured using an optrode (FOXY-R, $1.58 \mathrm{~mm}$ diameter, Ocean Optics, USA) connected to a spectrophotometer (USB2000, Ocean Optics), which logged $\mathrm{O}_{2}$ concentrations on a PC running Ocean Optics software (OOISensors, version 1.00.08, Ocean Optics). The optrode was calibrated using watersaturated air at the measurement temperature and a zero solution of sodium sulfite $\left(\mathrm{Na}_{2} \mathrm{SO}_{3}\right)$ and $0.01 \mathrm{~mol} \mathrm{~L}^{-1}$ sodium tetraborate $\left(\mathrm{Na}_{2} \mathrm{~B}_{4} \mathrm{O}_{7}\right) . \mathrm{O}_{2}$ saturation during the trials was maintained between 80 and $100 \%$ by replenishing chambers with filtered $(1.0 \mu \mathrm{m})$ seawater from respective temperature and $\mathrm{pCO}_{2}$ treatments. Changes in $\mathrm{O}_{2}$ saturation were converted to $\mathrm{O}_{2}$ concentrations $\left(\mu \mathrm{mol} \mathrm{L}{ }^{-1}\right.$ ) using tabulated gas solubility at a known temperature and salinity [N. Ramsing and J. Gundersen at www.unisense.com, based on Garcia and Gordon 1992]. Rates of change in $\mathrm{O}_{2}$ concentrations were determined by regressing $\mathrm{O}_{2}$ concentration against time, and standardizing to the surface area of the coral tissue $\left(\mathrm{cm}^{2}\right)$ as determined by wax dipping (Stimson and Kinzie 1991). The relationship between $P^{\text {net }}$ and irradiance was described with a hyperbolic tangent function (Jassby and Platt 1976) that included an exponent for photoinhibition (e.g., $\beta$ ) at high irradiances (Platt et al. 1980) to account for photoinhibitory effects of high-light or high-temperature exposure known to occur in phytoplankton (Platt et al. 1980) and Symbiodinium (Smith et al. 2005):

$P^{\beta}=P_{\mathrm{s}}^{\beta}\left(1-e^{-a}\right) e^{-b}$

where $a=\alpha \mathrm{I} / P_{\mathrm{s}}^{\beta}, b=\beta I / P_{\mathrm{s}}^{\beta}, P^{\beta}$ is the rate of net primary productivity $\left(P^{\text {net }}\right), P_{\mathrm{s}}^{\beta}$ is the maximum rate of net photosynthesis accounting for photoinhibition, $\alpha$ is the initial slope of the light-limited portion of the curve, and $I$ is irradiance in $\mu \mathrm{mol}$ photons $\mathrm{m}^{-2} \mathrm{~s}^{-1}$. Hyperbolic tangent functions were fit to the productivity data by nonlinear regression using Systat 11 software (Systat, Inc., USA) and used to characterize the photosynthetic efficiency (alpha, $\alpha$ ) and $P^{\text {net }}$ under high-light conditions. The aforementioned curves describe the full biological relationship between $P^{\text {net }}$ and $I$ for a large range of irradiances supplied in the laboratory, with these intensities exceeding maximum intensities found on the study reef. Mean PAR at $3 \mathrm{~m}$ depth on Hobihu reef (measured between March 6 and 10, 2011, using a $4 \pi$ spherical quantum sensor (MkV-L, JFE Advantech Co., Kobe, Japan) between 0900-1500 hrs was $660 \pm 30 \mu \mathrm{mol}$ photons $\mathrm{m}^{-2} \mathrm{~s}^{-1}( \pm \mathrm{SE}, n=148)$. To compare the photosynthetic performance of corals under ecologically relevant conditions and following exposure to 
treatments, best-fit curves were used to calculate $P^{\text {net }}$ at $660 \mu \mathrm{mol}$ photons $\mathrm{m}^{-2} \mathrm{~s}^{-1}$ (hereafter $P_{660}^{n e t}$ ), and this metric, along with $\alpha$, and dark respiration, was compared among treatments. While inclusion of an exponent for photoinhibition $(\beta)$ improved the fit of the response curves to the empirical data, in situ irradiances were not sufficiently high to elicit photoinhibition on the reef, and therefore, $\beta$ was not employed as a dependent variable in the analysis.

Chlorophyll a concentration and Symbiodinium density

Chlorophyll $a$ concentration and Symbiodinium density were quantified by removing coral tissue from the skeleton using an airbrush filled with filtered seawater $(1.0 \mu \mathrm{m})$. Colonies were airbrushed into a plastic bag, producing 8-40 mL of slurry that was homogenized (Polytron PT2100, Kinematica, USA) prior to separating the Symbiodinium by centrifugation $(1,500 \times g)$. The Symbiodinium pellet was resuspended by vortexing in filtered seawater and used to measure chlorophyll $a$ concentration and symbiont density.

Symbiodinium used for chlorophyll determinations were frozen $\left(-4{ }^{\circ} \mathrm{C}\right.$ for $\left.24 \mathrm{~h}\right)$ and subsequently thawed $\left(4{ }^{\circ} \mathrm{C}\right.$ for $24 \mathrm{~h}$ ) and filtered onto a cellulose acetate membrane filter (3.0 $\mu \mathrm{m}$ pore size, Critical Process Filtration, USA) to which $3 \mathrm{~mL}$ of $90 \%$ acetone was added. Samples were refrigerated $\left(4{ }^{\circ} \mathrm{C}\right)$ in darkness for $36 \mathrm{~h}$, centrifuged $(1,500 \times g$ for $3 \mathrm{~min})$, and absorbances at 630 and $636 \mathrm{~nm}$ measured and used to calculate chlorophyll $a$ concentration using the trichromatic equations of Jeffrey and Humphrey (1975) for dinoflagellates. Chlorophyll $a$ concentration was standardized by algal cell (pg cell ${ }^{-1}$ ) and surface area $\left(\mu \mathrm{g} \mathrm{cm}^{-2}\right.$ ) of the coral. Symbiodinium density $\left(\right.$ cells $\mathrm{cm}^{-2}$ ) was determined by counting Symbiodinium in the homogenized slurry stripped from the coral colonies, with the counts completed using a hemocytometer ( $n=4$ counts). Preliminary data showed that the mean and standard deviation of replicate determinations of Symbiodinium density stabilized after four counts.

\section{Statistical analysis}

Response variables were compared among treatments using three-way nested ANOVA in which $\mathrm{pCO}_{2}$ and temperature were fixed effects, and tank was a random factor nested within treatment. The physical and chemical conditions in the treatments also were analyzed with this statistical model. Tank was removed from the model when not significant at $P \geq 0.25$ (Quinn and Keough 2002). Significant interactive effects were analyzed using a post hoc Tukey test. To test the statistical assumption of ANOVA, graphical analyses of residuals were employed. Analyses were performed using Systat 11 in a Windows operating system.

\section{Results}

\section{Tank parameters}

Physical and chemical conditions in the treatment tanks were maintained precisely (Table 1). Mean $\mathrm{pCO}_{2}$ treatments were $45.1 \pm 0.2$ and $85.1 \pm 0.5 \mathrm{~Pa}( \pm \mathrm{SE}, n=55-56)$ with mean $\mathrm{pCO}_{2}$ across treatment tanks ranging from 43.6 to $47.0 \mathrm{~Pa}$ $\left(\mathrm{A}-\mathrm{CO}_{2}\right)$ and 83.2 to $87.2 \mathrm{~Pa}\left(\mathrm{H}-\mathrm{CO}_{2}\right)$. $\mathrm{pCO}_{2}$ differed between replicate tanks $\left(F_{4,103}=3.673, P=0.008\right)$ and treatments $\left(F_{1,4}=1798.18, P=<0.001\right)$, and $\mathrm{pH}_{\mathrm{T}}$ differed between replicate tanks $\left(F_{4,103}=5.956, P<0.001\right)$ and between $\mathrm{pCO}_{2}$ treatments $\left(F_{1,4}=1120.272\right.$, $P=<0.001)$. The tank effects for $\mathrm{pCO}_{2}$ and $\mathrm{pH}$ reflected differences of $<0.04 \mathrm{pH}_{\mathrm{T}}$ and $\leq 4.0 \mathrm{~Pa} \mathrm{pCO}_{2}$. For seawater temperatures, tank effects were not detected $\left(F_{4,176}=1.261\right.$,

Table 1 Summary of physical and chemical conditions in the 8 treatment tanks between July 28 and August 11, 2011

\begin{tabular}{|c|c|c|c|c|c|c|c|}
\hline Treatment & Tank & Temperature $\left({ }^{\circ} \mathrm{C}\right)$ & $\mathrm{pH}_{\text {total }}^{\dagger}$ & $\mathrm{TA}\left(\mu \mathrm{mol} \mathrm{kg}{ }^{-1}\right)$ & $\mathrm{pCO}_{2}(\mathrm{~Pa})$ & $\mathrm{HCO}_{3}{ }^{-}\left(\mu \mathrm{mol} \mathrm{kg}{ }^{-1}\right)$ & $\mathrm{CO}_{3}{ }^{2-}\left(\mu \mathrm{mol} \mathrm{kg}{ }^{-1}\right)$ \\
\hline \multirow[t]{2}{*}{$\mathrm{AT}-\mathrm{ACO}_{2}$} & 2 & $27.6 \pm 0.02(23)$ & $7.99(14)$ & $2196 \pm 8$ & $45.4 \pm 0.3(14)$ & $1724 \pm 5.1$ & $192 \pm 1.7(14)$ \\
\hline & 4 & $27.7 \pm 0.13$ & 7.99 (14) & $2184 \pm 7(14)$ & $44.6 \pm 0.3(14)$ & $1712 \pm 4.5(14)$ & $192 \pm 1.4(14)$ \\
\hline \multirow[t]{2}{*}{$\mathrm{HT}-\mathrm{ACO}_{2}$} & 3 & $30.4 \pm 0.14$ & $8.01(14)$ & $2217 \pm 8$ & $43.6 \pm 0.5$ & $1687 \pm 6.3(14)$ & $216 \pm 1.8$ \\
\hline & 8 & $30.6 \pm 0.02(23)$ & 7.98 (14) & $2219 \pm 7$ (14) & $46.7 \pm 0.4(14)$ & $1711 \pm 5.1(14)$ & $207 \pm 1.7$ (14) \\
\hline \multirow[t]{2}{*}{$\mathrm{AT}-\mathrm{HCO}_{2}$} & 1 & $27.7 \pm 0.03$ & $7.76(14)$ & $2208 \pm 7$ (14) & $86.1 \pm 0.6(14)$ & $1904 \pm 4.6(14)$ & $124 \pm 1.2(14)$ \\
\hline & 7 & $27.7 \pm 0.10$ & $7.75(13)$ & $2200 \pm 8$ & $87.1 \pm 0.9(13)$ & $1903 \pm 6.3(13)$ & $121 \pm 1.4(13)$ \\
\hline \multirow[t]{2}{*}{$\mathrm{HT}-\mathrm{HCO}_{2}$} & 5 & $30.6 \pm 0.13$ & 7.77 (14) & $2227 \pm 6(14)$ & $83.2 \pm 1.2(14)$ & $1884 \pm 3.4(14)$ & $141 \pm 2.1$ \\
\hline & 6 & $30.5 \pm 0.05(23)$ & 7.77 (14) & $2222 \pm 7(14)$ & $84.2 \pm 0.8$ & $1883 \pm 4.7(14)$ & $139 \pm 1.5(14)$ \\
\hline
\end{tabular}

Seawater chemistry was assessed daily and temperature three times daily $(0900,1200,1700 \mathrm{~h})$ in all tanks. Values displayed are mean $\pm \mathrm{SE}(n)$ $T A$ total alkalinity, $A T-A C \mathrm{O}_{2}$ ambient temperature-ambient $\mathrm{pCO}_{2}, H T-A C \mathrm{O}_{2}$ high temperature-ambient $\mathrm{pCO}_{2}, A T-H C \mathrm{O}_{2}$ ambient temperaturehigh $\mathrm{pCO}_{2}, \mathrm{HT}-\mathrm{HCO}_{2}$ high temperature-high $\mathrm{pCO}_{2}$

$+\mathrm{SE}<0.1$ 
$P=0.287)$, and mean temperatures $( \pm \mathrm{SE}, n=92)$ were $27.65 \pm 0.04{ }^{\circ} \mathrm{C}(\mathrm{AT})$ and $30.53 \pm 0.05{ }^{\circ} \mathrm{C}(\mathrm{HT})$.

\section{Photochemical efficiency}

Corals were acclimated to laboratory conditions prior to being placed into treatments. The progress of laboratory acclimation was monitored through daily measures of $F_{\mathrm{v}} / F_{\mathrm{m}}$ using 10 corals selected randomly each day. We inferred that acclimation was complete when $F_{\mathrm{v}} / F_{\mathrm{m}}$ did not vary among days. After 5 days (when $F_{\mathrm{v}} / F_{\mathrm{m}}$ stabilized), corals were placed in treatments and $\Delta F / F_{\mathrm{m}}{ }^{\prime}$ and $F_{\mathrm{v}} / F_{\mathrm{m}}$ measured every second day (data not shown) with this regime revealing declines at HT (but not other treatments) after 7 days. After 13 days, corals at $\mathrm{HT}$ experienced a $15 \%\left(\mathrm{HT}-\mathrm{HCO}_{2}\right)$ and $16 \%\left(\mathrm{HT}-\mathrm{ACO}_{2}\right)$ reduction in $\Delta F / F_{\mathrm{m}}{ }^{\prime}(P<0.05)$ compared to corals in the $\mathrm{AT}-\mathrm{ACO}_{2}$ treatment (Fig. 1). Mean $F_{\mathrm{v}} / F_{\mathrm{m}}$ was depressed 13 and $9 \%$ in $\mathrm{HT}-\mathrm{ACO}_{2}$ and $\mathrm{HT}-$ $\mathrm{HCO}_{2}$ treatments, respectively, versus AT-ACO $2(P<0.05)$ (Fig. 1). No significant effect $(P>0.25)$ of tank was detected for $F_{\mathrm{v}} / F_{\mathrm{m}}$, and tank was dropped from this analysis. While tank also was not significant for $\Delta F / F_{\mathrm{m}}{ }^{\prime}(P=0.193)$, it was retained in the analysis. $\Delta F / F_{\mathrm{m}}{ }^{\prime}$ was affected by temperature $\left(F_{1,4}=96.726, P=0.001\right)$ and was reduced at HT relative to AT. However, $\Delta F / F_{\mathrm{m}}{ }^{\prime}$ was not affected by $\mathrm{pCO}_{2}\left(F_{1,4}=0.775, P=0.428\right)$, and there was no temperature $\times \mathrm{pCO}_{2}$ interaction $\left(F_{1,4}=0.0001, P=0.993\right)$. Similarly, corals at HT exhibited reduced $F_{\mathrm{v}} / F_{\mathrm{m}}$ and were affected by temperature $\left(F_{1,48}=63.711, P<0.001\right)$ but not $\mathrm{pCO}_{2}\left(F_{1,48}=2.595, P=0.114\right)$, and there was no temperature $\times \mathrm{pCO}_{2}$ interaction $\left(F_{1,48}=0.307, P=0.582\right)$.

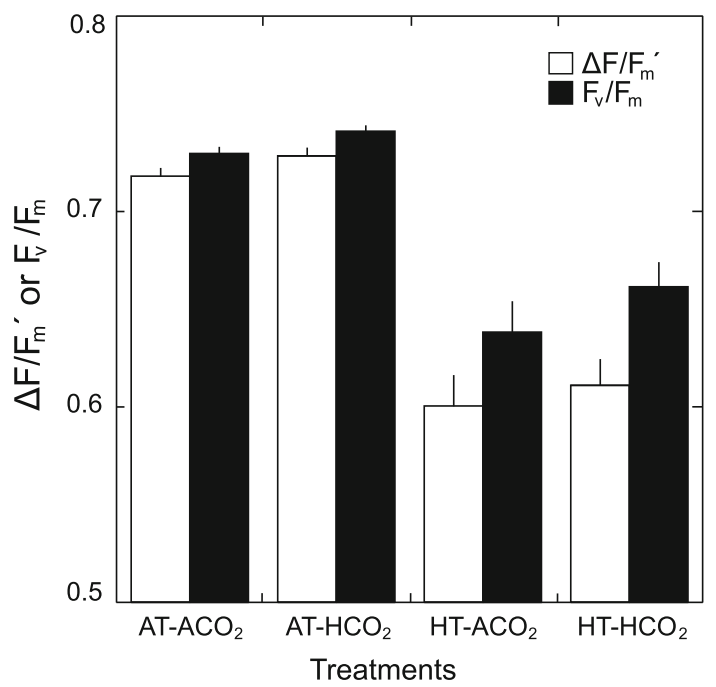

Fig. 1 Effective photochemical efficiency of RCIIs in actinic light $\left(\Delta F / F_{\mathrm{m}}{ }^{\prime}\right)\left(\sim 266 \mu \mathrm{mol}\right.$ photons $\left.\mathrm{m}^{-2} \mathrm{~s}^{-1}\right)$ and maximum photochemical efficiency of open RCIIs $\left(F_{\mathrm{v}} / F_{\mathrm{m}}\right)$ for juvenile Seriatopora caliendrum exposed for 14 days to combinations of temperature and $\mathrm{pCO}_{2}$ (Table 1). Values displayed are mean $\pm \mathrm{SE}$ $\left(n=13-14\right.$ treatment $\left.^{-1}\right)$
P/I curves

Net photosynthesis standardized to area $\left(\mathrm{cm}^{2}\right)$ increased with irradiance and developed asymptotes at $>400 \mu \mathrm{mol}$ photons $\mathrm{m}^{-2} \mathrm{~s}^{-1}$ in 7 cases, with slight declines in $P^{\text {net }}$ at high irradiances for 2 corals in the $\mathrm{HT}-\mathrm{ACO}_{2}$ treatment. Overall, however, mean ( \pm SE, $n=5-6)$ values for $\beta$ ranged from $0.030 \pm 0.020 \quad\left(\mathrm{HT}-\mathrm{ACO}_{2}\right) \quad$ to $0.006 \pm 0.002 \mu \mathrm{mol}$ $\mathrm{O}_{2} \mathrm{~cm}^{-2} \mathrm{~h}^{-1}$ ( $\mu$ mol photons $\left.\mathrm{m}^{-2} \mathrm{~s}^{-1}\right)^{-1}\left(\mathrm{HT}-\mathrm{HCO}_{2}\right)$, and these declines did not begin until ecologically relevant irradiances from the collection depth had been exceeded. The hyperbolic tangent functions with photoinhibition fit the photosynthesis data well (mean $r^{2}=0.95$ ) and were used to calculate values for $\alpha$ and $P_{660}^{n e t}$ for corals in each treatment $\left(n=5-6\right.$ treatment $\left.^{-1}\right)$. Dark respiration was calculated directly from raw data (Table 2). Tank effects were not significant for respiration or $P_{660}^{n e t}(P>0.25)$, and therefore, tank was dropped from these analyses. Tank was retained in the analysis of $\alpha$ (Tank $P=0.216)$.

Area-normalized respiration ranged from $0.96 \pm 0.06$ to $0.73 \pm 0.07 \mu$ mol $\mathrm{O}_{2} \mathrm{~cm}^{-2} \mathrm{~h}^{-1}$ (mean $\pm \mathrm{SE}, \mathrm{n}=5-6$, Table 2) and was not affected by temperature, $\mathrm{pCO}_{2}$, or the interaction between the two (Table 3 ). Temperature significantly affected $P_{660}^{n e t}$ standardized to area $(P<0.001)$; no effect of $\mathrm{pCO}_{2}$ or the temperature $\times \mathrm{pCO}_{2}$ interaction was detected (Table 3). Area-normalized $P_{660}^{n e t}$ decreased $95 \%$ at $\mathrm{HT}-\mathrm{ACO}_{2}$ compared to $\mathrm{AT}-\mathrm{ACO}_{2}$ and was affected similarly at $\mathrm{HCO}_{2}$, being reduced $89 \%$ at $\mathrm{HT}$ compared to AT (Fig. 2). Alpha was affected by temperature $(P<0.001)$ but not $\mathrm{pCO}_{2}$, or the interaction between the two.

\section{Chlorophyll a and Symbiodinium density}

After 2 weeks in the treatments, corals in AT treatments appeared a normal color while corals in the HT treatment showed signs of bleaching, although no corals died. When normalized to area, mean concentration of chlorophyll $a$ ranged from $13.35 \pm 0.43 \mu \mathrm{g} \mathrm{cm}^{-2}$ in $\mathrm{AT}-\mathrm{ACO}_{2}$ to $3.73 \pm 0.43 \mu \mathrm{g} \mathrm{cm}^{-2}$ in $\mathrm{HT}-\mathrm{ACO}_{2}( \pm \mathrm{SE}, n=12-14)$ (Fig. 3a). The interaction of temperature and $\mathrm{pCO}_{2}$ was significant $\left(F_{1,48}=5.074, P=0.029\right)$ due to a $13 \%$ reduction in chlorophyll $a \mathrm{~cm}^{-2}$ between $\mathrm{AT}-\mathrm{ACO}_{2}$ and $\mathrm{AT}-\mathrm{HCO}_{2}$, and a $25 \%$ increase in $\mathrm{HT}-\mathrm{HCO}_{2}$ compared to $\mathrm{HT}-\mathrm{ACO}_{2}$ (Fig. 3a). Chlorophyll a concentration was affected by temperature $\left(F_{1,48}=193.646, P<0.001\right)$, but not $\mathrm{pCO}_{2}\left(F_{1,48}=0.457, P=0.502\right)$, and post hoc analyses revealed $\mathrm{A}-\mathrm{CO}_{2}$ and $\mathrm{H}-\mathrm{CO}_{2}$ conditions within temperature treatments (i.e., 27.7 and $30.5^{\circ} \mathrm{C}$ ) were not significantly different from each other $(P>0.05)$ (Fig. 3a). When normalized to Symbiodinium cells, chlorophyll $a$ concentration was unaffected by temperature $\left(F_{1,28}=0.143, P=0.709\right)$, 
Table 2 Dark respiration and parameters describing the relationship between net photosynthesis $\left(\mu \mathrm{mol} \mathrm{O}_{2} \mathrm{~cm}^{-2} \mathrm{~h}^{-1}\right)$ and irradiance $(\mu \mathrm{mol}$ photons $\left.\mathrm{m}^{-2} \mathrm{~s}^{-1}\right)(P / I)$ standardized by area for juvenile Seriatopora caliendrum

\begin{tabular}{|c|c|c|c|c|}
\hline \multirow[t]{2}{*}{ Parameter } & \multicolumn{4}{|l|}{ Treatments } \\
\hline & $\mathrm{AT}-\mathrm{ACO}_{2}$ & $\mathrm{AT}-\mathrm{HCO}_{2}$ & $\mathrm{HT}-\mathrm{ACO}_{2}$ & $\mathrm{HT}-\mathrm{HCO}_{2}$ \\
\hline$R\left(\mu \mathrm{mol} \mathrm{O}_{2} \mathrm{~cm}^{-2} \mathrm{~h}^{-1}\right)$ & $0.96 \pm 0.06(6)$ & $0.75 \pm 0.04(5)$ & $0.73 \pm 0.07(5)$ & $0.75 \pm 0.08(6)$ \\
\hline$P_{660}^{n e t}\left(\mu \mathrm{mol} \mathrm{O}_{2} \mathrm{~cm}^{-2} \mathrm{~h}^{-1}\right)$ & $1.80 \pm 0.44(6)$ & $1.96 \pm 0.29(6)$ & $0.08 \pm 0.09(5)$ & $0.22 \pm 0.09(6)$ \\
\hline $\begin{array}{l}\alpha\left(\mu \mathrm{mol} \mathrm{O}_{2} \mathrm{~cm}^{-2} \mathrm{~h}^{-1}\right) \\
\left(\mu \mathrm{mol} \text { photons } \mathrm{m}^{-2} \mathrm{~s}^{-1}\right)^{-1}\end{array}$ & $0.013 \pm 0.0007(6)$ & $0.011 \pm 0.0004(6)$ & $0.004 \pm 0.0005$ & $0.004 \pm 0.0003(6)$ \\
\hline
\end{tabular}

Corals were incubated for 14 days in combinations of temperature $\left({ }^{\circ} \mathrm{C}\right)$ and $\mathrm{pCO}_{2}(\mathrm{~Pa})(\mathrm{Table} 1)$. Parameters were obtained from the best-fit hyperbolic tangent with an exponent for photoinhibition (Platt et al. 1980). Values displayed are mean \pm SE ( $n=$ number of corals)

$R$ respiration; Chl a chlorophyll $a, P_{660}^{n e t}$ rate of net photosynthesis as measured at $660 \mu \mathrm{mol}$ photons $\mathrm{m}^{-2} \mathrm{~s}^{-1}, \alpha$ the initial slope of the lightlimited portion of the curve

Table 3 Statistical analysis of photosynthesis versus irradiance $(P / I)$ curve parameters standardized by surface area for juvenile Seriatopora caliendrum exposed to different treatments

\begin{tabular}{|c|c|c|c|c|c|}
\hline Dependent variable & Effect & $d f$ & $M S$ & $F$ & $P$ \\
\hline \multirow[t]{4}{*}{ Respiration $\left(\mu \mathrm{mol} \mathrm{O} \mathrm{Cm}^{-2} \mathrm{~h}^{-1}\right)$} & $\mathrm{pCO}_{2}$ & 1 & 0.044 & 1.823 & 0.194 \\
\hline & Temp & 1 & 0.070 & 2.930 & 0.104 \\
\hline & $\mathrm{pCO}_{2} \times \mathrm{Temp}$ & 1 & 0.070 & 2.912 & 0.105 \\
\hline & Error & 18 & 0.024 & & \\
\hline \multirow[t]{4}{*}{$P_{660}^{n e t}\left(\mu \mathrm{mol} \mathrm{O} \mathrm{cm}^{-2} \mathrm{~h}^{-1}\right)$} & $\mathrm{pCO}_{2}$ & 1 & 0.132 & 0.291 & 0.596 \\
\hline & Temp & 1 & 17.078 & 32.728 & $<0.001$ \\
\hline & $\mathrm{pCO}_{2} \times$ Temp & 1 & 0.001 & 0.001 & 0.974 \\
\hline & Error & 19 & 0.453 & & \\
\hline \multirow{5}{*}{$\begin{array}{l}\alpha \\
\left(\mu \mathrm{mol} \mathrm{O}_{2} \mathrm{~cm}^{-2} \mathrm{~h}^{-1}\right) \\
\left(\mu \mathrm{mol} \text { photons } \mathrm{m}^{-2} \mathrm{~s}^{-1}\right)^{-1}\end{array}$} & $\mathrm{pCO}_{2}$ & 1 & $4.00 \times 10^{-6}$ & 2.162 & 0.215 \\
\hline & Temp & 1 & $3.43 \times 10^{-4}$ & 171.417 & $<0.001$ \\
\hline & $\mathrm{pCO}_{2} \times \mathrm{Temp}$ & 1 & $2.00 \times 10^{-6}$ & 1.103 & 0.353 \\
\hline & Tank $\left(\mathrm{pCO}_{2} \times\right.$ Temp $)$ & 4 & $2.00 \times 10^{-6}$ & 1.639 & 0.216 \\
\hline & Error & 15 & $1.00 \times 10^{-6}$ & & \\
\hline
\end{tabular}

Analyses were performed using a partly nested ANOVA with two fixed factors ( $\mathrm{pCO}_{2}$ and Temperature) and one nested factor (Tank). Tank was dropped from the analysis when $P>0.25$; significant values $(P<0.05)$ are in bold

Chl $a$ chlorophyll $a$, $d f$ degrees of freedom, $M S$ mean sum of squares, parameter definitions in Table 2

$\mathrm{pCO}_{2}\left(F_{1,28}=0.181, \quad P=0.673\right)$, or the interaction between the two $\left(F_{1,28}=0.001, P=0.975\right)$ (Fig. 3a-inset).

Symbiodinium densities standardized to area were affected by temperature $\left(F_{1,28}=104.676, P<0.001\right)$ but not $\mathrm{pCO}_{2}\left(F_{1,28}=0.315, P=0.579\right)$, or the interaction between the two $\left(F_{1,28}=0.343, P=0.563\right)$. Mean Symbiodinium densities decreased $69 \%$ in $\mathrm{HT}-\mathrm{ACO}_{2}$ compared to $\mathrm{AT}-\mathrm{ACO}_{2}$, and $65 \%$ in $\mathrm{HT}-\mathrm{HCO}_{2}$ compared to AT- $\mathrm{HCO}_{2}$ (Fig. 3b).

\section{Discussion}

OA and coral bleaching

Large-scale thermal bleaching is a major cause of declining coral cover (Wilkinson 2008), and therefore, reports that elevated $\mathrm{pCO}_{2}$ can induce bleaching at a magnitude equivalent to thermally induced bleaching (Anthony et al. 2008) have received much attention. Despite this attention, there has not been a rigorous test of the hypothesis that OA affects the same physiological processes that underpin thermal bleaching (Warner et al. 1996; Fitt et al. 2001; but see Brading et al. 2011). In the present study, bleaching of $S$. caliendrum at elevated temperature and high $\mathrm{pCO}_{2}$ was evaluated at three functional levels corresponding to the sequence of events taking place during the onset of bleaching (Fitt et al. 2001). High $\mathrm{pCO}_{2}(85.1 \mathrm{~Pa})$ did not cause bleaching, either individually, or interactively with high temperature.

Our results draw attention to the inconsistencies in the reported effects of high $\mathrm{pCO}_{2}$ in directly (or indirectly) causing coral bleaching. For instance, our findings are contrary to reports that $\mathrm{pCO}_{2}$ as high as $152.0 \mathrm{~Pa}$ causes 


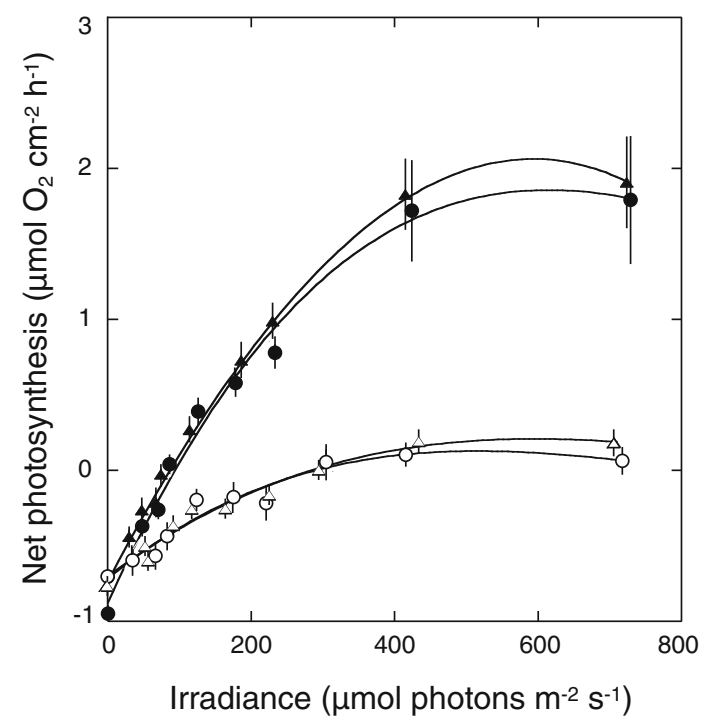

Fig. 2 Net photosynthesis $\left(P^{\text {net }}\right)$ versus irradiance $(P / I)$ curves for juvenile Seriatopora caliendrum exposed for 14 days to combinations of temperature and $\mathrm{pCO}_{2}$ as described in Table 1. Symbols correspond to treatments $\mathrm{AT}-\mathrm{ACO}_{2}$ (dark circles), $\mathrm{HT}-\mathrm{ACO}_{2}$ (open circles), $\mathrm{AT}-\mathrm{HCO}_{2}$ (dark triangles), and $\mathrm{HT}-\mathrm{HCO}_{2}$ (open triangles). At each irradiance, values are mean $P^{\text {net }} \pm \mathrm{SE}(n=5-6)$; best-fit lines are fit to mean $P^{\text {net }}$ values

bleaching in Acropora intermedia and Porites lobata (Anthony et al. 2008) and leads to declines in net productivity of Stylophora pistillata (Reynaud et al. 2003), A. intermedia and P. lobata (Anthony et al. 2008; Crawley et al. 2010). Additionally, while elevated $\mathrm{pCO}_{2}$ reduced photochemical efficiency in Porites australiensis $\left(F_{\mathrm{v}} / F_{\mathrm{m}}\right.$; Iguchi et al. 2011) and massive Porites spp. $\left(F_{\mathrm{v}} / F_{\mathrm{m}}\right.$ and $\Delta F / F_{\mathrm{m}}{ }^{\prime}$; Edmunds 2012), and increased concentration of chlorophyll $a$ per algal cell in $S$. pistillata (e.g., photoacclimation; Crawley et al. 2010), we found no effect of $\mathrm{pCO}_{2}$ on photochemical efficiency and the content of chlorophyll $a \mathrm{~cm}^{-2}$ or chlorophyll $a$ cell $^{-1}$. However, our results are consistent with several other studies showing that $\mathrm{pCO}_{2}$ as high as $227 \mathrm{~Pa}$ has no effect on photosynthesis in Acropora eurystoma (Schneider and Erez 2006) or S. pistillata (Godinot et al. 2011). Further, high $\mathrm{pCO}_{2}$ has no effect on $F_{\mathrm{v}} / F_{\mathrm{m}}$ in S. pistillata (Godinot et al. 2011), or chlorophyll content $\left(a+c_{2}\right)$ and Symbiodinium density in $P$. australiensis (Iguchi et al. 2011). While 14-day exposure to elevated $\mathrm{pCO}_{2}$ in the present study did not result in bleaching, elevated temperature reduced both photosynthetic performance and symbiont and photopigment density, as has previously been reported (Hoegh-Guldberg and Smith 1989; Warner et al. 1999; Anthony et al. 2008). This result reaffirms the importance of rising SST in negatively affecting corals (Hoegh-Guldberg et al. 2007) and underscores the possibility that corals could succumb to the effects of high temperature before they are impacted seriously by high $\mathrm{pCO}_{2}$ (Hoegh-Guldberg et al. 2007).

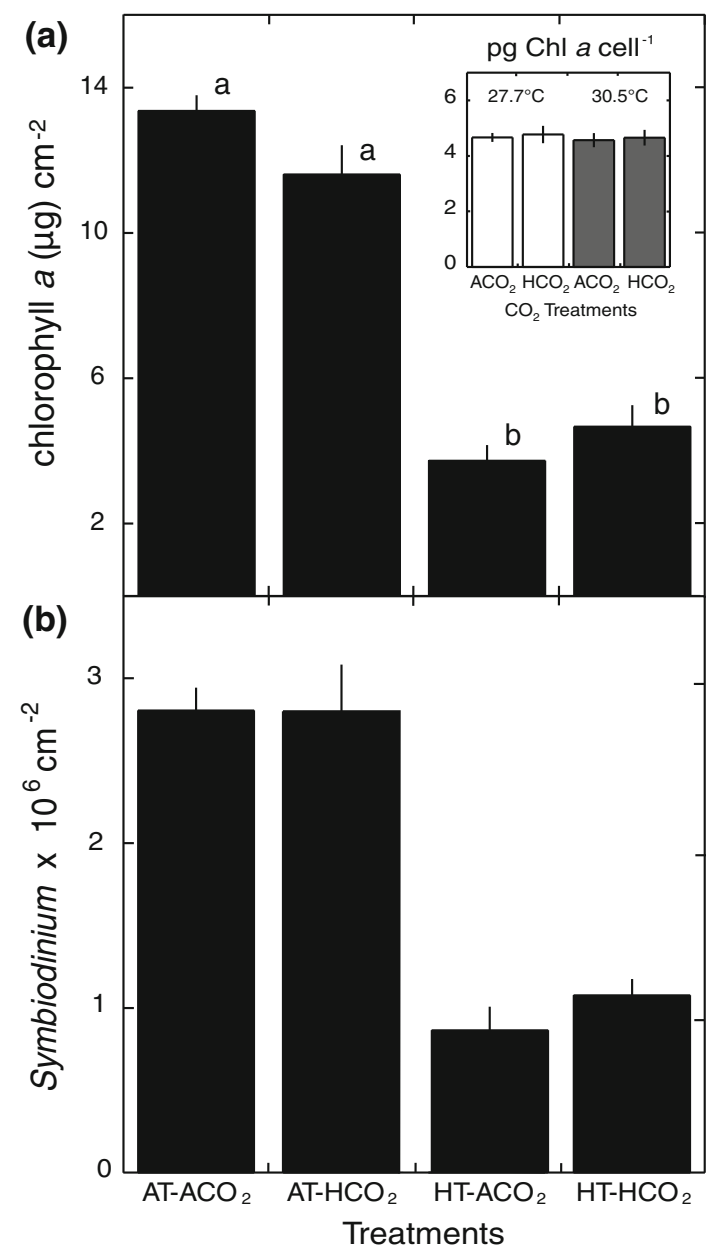

Fig. 3 Chlorophyll $a$ normalized to area and Symbiodinium cells, and the density of Symbiodinium spp. in juvenile Seriatopora caliendrum exposed for 14 days to combinations of temperature and $\mathrm{pCO}_{2}$ (Table 1). a Chlorophyll $a\left(\mu \mathrm{g} \mathrm{cm}^{-2}\right)\left(n=12-14\right.$ treatment $\left.^{-1}\right)$ with inset showing chlorophyll $a$ content per Symbiodinium cell at $27.7^{\circ} \mathrm{C}$ (white columns), $30.5{ }^{\circ} \mathrm{C}$ (gray columns), and 45.1 and $85.1 \mathrm{~Pa} \mathrm{CO}_{2}$; (b) Symbiodinium spp. density per surface area of coral tissue $\left(\mathrm{cm}^{-2}\right)$ $\left(n=8\right.$ treatment $\left.^{-1}\right)$. Values displayed are mean $\pm \mathrm{SE}$; letters indicate post hoc multiple comparisons with dissimilar letters marking treatments that differed $(P<0.05)$

\section{Onset of bleaching}

Previous evidence that OA directly affects one of the proximal processes (i.e., photochemical efficiency) driving coral bleaching is equivocal, but the present results clearly support a null effect for high $\mathrm{pCO}_{2}$. It is unclear what factors are responsible for conflicting $\mathrm{pCO}_{2}$ effects on Symbiodinium photochemical efficiency among studies; however, OA effects on coral calcification are modulated by light intensity (Dufault et al. 2013; Suggett et al. 2013) and light intensity may also provide insight into the disparate effects of $\mathrm{OA}$ on photochemical efficiency. Numerous OA studies have been performed under subsaturating low light intensities $(<10-150 \mu \mathrm{mol}$ photons 
$\mathrm{m}^{-2} \mathrm{~s}^{-1}$ ) (e.g., Crawley et al. 2010; Iguchi et al. 2011) that may not be ecologically relevant to corals in situ. We acknowledge light intensities employed here $(265 \mu \mathrm{mol}$ photons $\mathrm{m}^{-2} \mathrm{~s}^{-1}$ ) were below field irradiances; however, light intensity exceeded the saturation irradiance $\left(I_{k}=P_{\max } / \alpha\right)$ for photosynthesis in these corals $\left(I_{k}=144 \pm 3 \mu \mathrm{mol}\right.$ photons $\mathrm{m}^{-2} \mathrm{~s}^{-1}[ \pm \mathrm{SE}, n=3]$, C.B. Wall pers comm). Under subsaturating irradiances, energy dissipation pathways (e.g., NPQ) are less active than under saturating irradiances. However, OA appears to prematurely activate energy dissipation pathways (Crawley et al. 2010), which may result in reduced photochemical efficiency and productivity. At low light intensities, the effects of OA on photochemical efficiency may be masked due to various factors, including the coral's previous light history, low levels of NPQ (i.e., reducing $\Delta F / F_{\mathrm{m}}{ }^{\prime}$ ) and PSII photoinactivation (i.e., reducing $F_{\mathrm{v}} / F_{\mathrm{m}}$ ), and efficient turnover of the D1 protein of PSII. Therefore, $\mathrm{CO}_{2}$ effects under low light intensities may only manifest under prolonged incubations, or under short incubation at high irradiances (Edmunds 2012). It is clear that further research on the interaction of light and $\mathrm{OA}$ in affecting photochemical efficiency will be required to resolve these issues.

\section{Intermediate events associated with bleaching}

The $\mathrm{pCO}_{2}$-enrichment alone, or in combination with high temperature (HT), did not affect the dark respiration of $S$. caliendrum, or their photosynthetic efficiency $(\alpha)$ and photosynthetic capacity $\left(P_{660}^{n e t}\right)$. However, in HT treatments, concurrent with decreased $F_{\mathrm{v}} / F_{\mathrm{m}}$ and $\Delta F / F_{\mathrm{m}}{ }^{\prime}$, large reduction in $P_{660}^{\text {net }}$ and $\alpha$ was observed, while dark respiration remained unchanged. Under prolonged exposure to high light intensities or elevated temperatures, photoprotective mechanisms that normally shift energy away from PSII begin to breakdown, resulting in photo-oxidative damage to PSII, reduced photosynthetic productivity, and ultimately, bleaching (Lesser 1997; Warner et al. 1999; Smith et al. 2005). In the present study, a reduction in $P_{660}^{n e t}$ associated with elevated temperature may be attributed to several processes including reduced densities of Symbiodinium or the number of photosynthetic units (PSU), and a slower turnover rate of PSII and the D1 reaction center protein (Falkowski and Raven 1997; Warner et al. 1999). Photodamage and decreased turnover rates of the D1 protein are associated with the onset of thermal bleaching in corals (Warner et al. 1999), as well as in heat-stressed Symbiodinium in vitro (Iglesias-Prieto et al. 1992) and more generally, in marine diatoms and natural phytoplankton assemblages undergoing photoinhibition in situ (Behrenfeld et al. 1998). Decreases in $\alpha$ of colonies of $S$. caliendrum exposed to HT treatments indicates a diminished integrity of RCIIs, potentially arising from photo-oxidative damage to the D1 protein of RCIIs (Lesser 1997; Warner et al. 1999), and fewer photons absorbed by the antennae complex being transferred to the acceptor side of PSII (Falkowski and Raven 1997).

The null effect of $\mathrm{pCO}_{2}$ treatments on coral respiration agrees with studies, showing no effect of $\mathrm{pCO}_{2}$ (up to $217 \mathrm{~Pa}$ ) on the dark respiration of S. pistillata (Reynaud et al. 2003; Crawley et al. 2010; Godinot et al. 2011), Acropora intermedia or Porites lobata (120.1 Pa) (Anthony et al. 2008), A. eurystoma (56.0 Pa) (Schneider and Erez 2006), and Porites spp. at $76.6 \mathrm{~Pa}$ (Edmunds 2012) and $99 \mathrm{~Pa}$ (Wall and Edmunds 2013), but conflict with studies reporting OA reduces coral respiration (Edmunds 2012). In the present study, high flow rates may have stimulated coral respiration across treatments by reducing the diffusion boundary layer (DBL) across the corals tissue (Lesser et al. 1994), thereby reducing the ability to detect a treatment effect on respiration. Alternatively, the disparity in OA effects on coral respiration may reflect differential responses to elevated external $\mathrm{CO}_{2}$ or reduced extracellular $\mathrm{pH}$, or the magnitude of the $\mathrm{pCO}_{2}$ treatments (Edmunds 2012).

The decrease in $\alpha$ and $P_{660}^{n e t}$ of $S$. caliendrum kept at $30.5^{\circ} \mathrm{C}$ is consistent with studies showing a decrease in the photosynthetic performance of Symbiodinium in hospite (Coles and Jokiel 1977) and in vitro (Iglesias-Prieto et al. 1992) for corals exposed to elevated temperatures $\left(>28{ }^{\circ} \mathrm{C}\right)$. However, 85.1 $\mathrm{Pa} \mathrm{pCO}_{2}$ did not affect the lightlimited efficiency of photosynthesis $(\alpha)$ or the rate of photosynthesis of $S$. caliendrum at mean in situ irradiances (i.e., $\left.P_{660}^{n e t}\right)$. These findings are in agreement with studies with corals showing no effect of $\mathrm{pCO}_{2}$ (up to $152 \mathrm{~Pa}$ ) on the capacity for photosynthesis (Langdon and Atkinson 2005; Schneider and Erez 2006) and photosynthetic efficiency (Crawley et al. 2010) of Symbiodinium. While coral photosynthesis appears insensitive to changes in $\mathrm{pH}$ (Goiran et al. 1996; Schneider and Erez 2006), it has been suggested that rates of Symbiodinium photosynthesis are carbon limited under ambient [DIC] of $\sim 2,000 \mu \mathrm{mol} \mathrm{kg}$ (Herfort et al. 2008), and therefore, increase dissolved $\mathrm{CO}_{2}$ or elevated [DIC] $\left(\sim 200 \mu \mathrm{mol} \mathrm{kg}{ }^{-1}\right.$ primarily in the form of $\mathrm{HCO}_{3}{ }^{-}$) from $\mathrm{OA}$ could stimulate photosynthesis, although the general consensus is that Symbiodinium productivity is not stimulated by $10 \%$ increase in [DIC].

Variability in abiotic factors, such as PAR or seawater temperature, may influence the impacts of OA on corals and the performance of their Symbiodinium, particularly in short- versus long- term experiments. However, disparities in effects of OA on photosynthesis of corals may also reflect genetic variability in the response of Symbiodinium to environmental disturbance (Ragni et al. 2010; Putnam 
et al. 2012), or differential reliance of the algae on CCMs versus $\mathrm{CO}_{2(\mathrm{aq})}$ to supply carbon for photosynthesis (sensu Brading et al. 2011). For instance, the response of four cultured Symbiodinium phylotypes (Brading et al. 2011) to high $\mathrm{pCO}_{2}$ is phylotype-specific. However, the role(s) played by Symbiodinium phylotypes in the response of corals to OA is uncertain, first because it is unknown what phylotypes associate with $S$. caliendrum in southern Taiwan (although, S. hystrix on the Great Barrier Reef associates with 5 phylotypes of clade C Symbiodinium, Bongaerts et al. 2010), and further, the microenvironment surrounding Symbiodinium in hospite differs from the external environment (Venn et al. 2009). The coral host is thought to exert strong control over the photosynthetic performance of Symbiodinium (Gates et al. 1999), and therefore, the effects of OA on Symbiodinium in hospite are likely to be modulated by the host.

\section{Terminal stages of bleaching}

The terminal stages of coral bleaching involve a reduction in photopigment content of Symbiodinium and the expulsion of symbionts (Fitt et al. 2001). In the present study, 14 days at $30.5{ }^{\circ} \mathrm{C}$ led to declines in the density of Symbiodinium and reductions in their chlorophyll $a$ content, but neither trait was affected by high $\mathrm{pCO}_{2}$. Crawley et al. (2010) reported no change in Symbiodinium densities, but an increase in chlorophyll $a$ content cell $^{-1}$ in response to high $\mathrm{pCO}_{2}$ (38.5 vs. 70.9 and $111.5 \mathrm{~Pa}$ ), and suggested that OA elicits photoacclimation by Symbiodinium. While chlorophyll concentration in $S$. caliendrum was not affected by $\mathrm{pCO}_{2}$ alone, the $\mathrm{pCO}_{2} \times$ temperature interaction led to reduction in chlorophyll $a$ at $27.7{ }^{\circ} \mathrm{C}$ and increases at $30.5^{\circ} \mathrm{C}$ relative to $45.1 \mathrm{~Pa}$. Similarly, 77.0 $\mathrm{Pa} \mathrm{pCO}_{2}$ decreased chlorophyll $a\left(\mathrm{mg}\right.$ protein $\left.{ }^{-1}\right)$ in $S$. pistillata at $25.2{ }^{\circ} \mathrm{C}$ and increased chlorophyll $a$ at $28.3{ }^{\circ} \mathrm{C}$, relative to 46.6 Pa (Reynaud et al. 2003). However, in the present study, chlorophyll $a$ (pg) cell ${ }^{-1}$ and Symbiodinium densities did not change in response to $\mathrm{pCO}_{2}$; therefore, the change in chlorophyll $a$ content is likely to be caused by symbiont expulsion and not photoacclimation. Using $S$. caliendrum, our results suggest $\mathrm{OA}$ interacts with temperature to affect the chlorophyll content of Symbiodinium, but this modulation of pigment content does not result in increased photosynthetic performance or ameliorated effects of thermal bleaching on the holobiont.

Acknowledgments This research was funded by the US National Science Foundation through Grant BIO-OCE 08-44785 (to PJE) and was submitted in partial fulfillment of the MS degree for CBW. We thank two anonymous reviewers for comments that improved an earlier draft of this paper, V.R. Cumbo, A.M. Dufault, E. Rivest and S. Zamudio for field assistance, and NMMBA for logistical support.
This is contribution number 200 of the Marine Biology Program of California State University, Northridge.

\section{References}

Anthony KRN, Kline DI, Diaz-Pulido G, Dove S, Hoegh-Guldberg O (2008) Ocean acidification causes bleaching and productivity loss in coral reef builders. Proc Natl Acad Sci USA 105:17442-17446

Behrenfeld MJ, Prasil O, Kolber ZS, Babin M, Falkowski PG (1998) Compensatory changes in photosystem II electron turnover rates protect photosynthesis from photoinhibition. Photosynth Res 58:259-268

Bongaerts P, Riginos C, Ridgway T, Sampayo EM, van Oppen MJH, Englebert N, Vermeulen F, Hoegh-Guldberg O (2010) Genetic Divergence across habitats in the widespread coral Seriatopora hystrix and its associated Symbiodinium. PLoS ONE 5:e10871

Brading P, Warner ME, Davey P, Smith DJ, Achterberg EP, Suggett DJ (2011) Differential effects of ocean acidification on growth and photosynthesis among phylotypes of Symbiodinium (Dinophyceae). Limnol Oceanogr 56:927-938

Caldiera K, Jain AK, Hoffert MI (2003) Climate sensitivity uncertainty and the need for energy without $\mathrm{CO}_{2}$ emission. Science 299:2052-2054

Chan NCS, Connolly SR (2013) Sensitivity of coral calcification to ocean acidification: a meta-analysis. Global Change Biol 19:282-290

Coles SL, Jokiel PL (1977) Effects of temperature on photosynthesis and respiration in hermatypic corals. Mar Biol 43:209-216

Cosgrove J, Borowitzka MA (2010) Chlrophyll fluorescence terminology: an introduction. In: Suggett DJ, Borowitzka MA, Prášil $\mathrm{O}$ (eds) Chlorophyll a fluorescence in aquatic sciences: methods and applications. Developments in Applied Phycology 4:1-17

Crawley A, Kline DI, Dunn S, Anthony K, Dove S (2010) The effect of ocean acidification on symbiont photorespiration and productivity in Acropora formosa. Global Change Biol 16:851-863

Dai C-F, Horng S (2009) Scleractinian fauna of Taiwan. National Taiwan University Press, Taipei, The robusta group

Dickson AG, Sabine CL, Christian JR (eds) (2007) Guide to best practices for ocean $\mathrm{CO}_{2}$ measurements. PICES special publication 3: North Pacific Marine Science Organization, British Columbia

Dufault AM, Ninokawa A, Bramanti L, Cumbo VR, Fan T-Y, Edmunds PJ (2013) The role of light in mediating the effects of ocean acidification on coral calcification. J Exp Biol. doi:10. 1242/jeb.080549

Dunn SR, Schnitzler CE, Weis VM (2007) Apoptosis and autophagy as mechanisms of dinoflagellate symbiont release during cnidarian bleaching: every which way you lose. Proc R Soc B 274:3079-3085

Edmunds PJ (2012) Effect of $\mathrm{pCO}_{2}$ on the growth, respiration and photophysiology of massive Porites spp. in Moorea French Polynesia. Mar Biol 159:2149-2160

Edmunds PJ, Davies PS (1988) Post-stimulation of respiration rates in the coral Porites porites. Coral Reefs 7:7-9

Falkowski PG, Raven JA (eds) (1997) Aquatic photosynthesis. Blackwell Science, Massachusetts

Fangue NA, O'Donnel MJ, Sewell MA, Matson PG, MacPherson AC, Hofmann GE (2010) A laboratory-based experimental system for the study of ocean acidification effects on marine invertebrate larvae. Limnol Oceanogr 8:441-452

Fitt WK, Brown BE, Warner ME, Dunne RP (2001) Coral bleaching: Interpretation of thermal tolerance limits and thermal thresholds in tropical corals. Coral Reefs 20:51-65

Garcia HE, Gordon LI (1992) Oxygen solubility in seawater: Better fitting equations. Limnol Oceanogr 37:1307-1312 
Gates RD, Baghdasarian G, Muscatine L (1992) Temperature stress causes host cell detachment in symbiotic cnidarians: implications for coral bleaching. Biol Bull 182:324-332

Gates RD, Bil KY, Muscatine L (1999) The influence of an anthozoan "host factor" on the physiology of a symbiotic dinoflagellate. J Exp Mar Biol Ecol 232:241-259

Glynn PW (1983) Extensive 'bleaching' and death of reef corals on the Pacific coast of Panamá. Environ Conserv 10:149-154

Glynn PW (1996) Coral reef bleaching: Facts, hypotheses and implications. Global Change Biol 2:495-509

Godinot $\mathrm{C}$, Houlbrèque F, Grover R, Ferrier-Pagès C (2011) Coral uptake of inorganic phosphorus and nitrogen negatively affected by simultaneous changes in temperature and $\mathrm{pH}$. PLoS ONE 6:e25024

Goiran C, Al-Moghrabi S, Allemand D, Jaubert J (1996) Inorganic carbon uptake for photosynthesis by symbiotic coral/dinoflagellate associations. I. Photosynthetic performances of symbionts and dependence on sea water bicarbonate. J Exp Mar Biol Ecol 199:207-225

Herfort L, Thake B, Taubner I (2008) Bicarbonate stimulation of calcification and photosynthesis in two hermatypic corals. J Phycol 44:91-98

Hill R, Ralph PJ (2008) Dark-induced reduction of the plastoquinone pool in zooxanthellae of scleractinian corals and implications for measurements of chlorophyll $a$ fluorescence. Symbiosis 46:45-56

Hill R, Frankart C, Ralph P (2005) Impact of bleaching conditions on the components of non-photochemical quenching in the zooxanthellae of a coral. J Exp Mar Biol Ecol 322:83-92

Hoegh-Guldberg O (1999) Climate change, coral bleaching and the future of the world's coral reefs. Mar Freshw Res 50:839-866

Hoegh-Guldberg O, Jones RJ (1999) Photoinhibition and photoprotection in symbiotic dinoflagellates from reef-building corals. Mar Ecol Prog Ser 183:73-86

Hoegh-Guldberg O, Smith GJ (1989) Influence of the population density of zooxanthellae and supply of ammonium on the biomass and metabolic characteristics of the reef corals Seriatopora hystrix and Stylophora pistillata. Mar Ecol Prog Ser 57:173-186

Hoegh-Guldberg O, Mumby PJ, Hooten AJ, Steneck RS, Greenfield P, Gomez E, Harvell CD, Sale PF, Edwards AJ, Caldeira K, Knowlton N, Eakin CM, Iglesias-Prieto R, Muthiga N, Bradbury RH, Dubi A, Hatziolos ME (2007) Coral reefs under rapid climate change and ocean acidification. Science 318:1737-1742

Iglesias-Prieto R, Matta JL, Robins WA, Trench RK (1992) Photosynthetic response to elevated temperature in the symbiotic dinoflagellate Symbiodinium microadriaticum in culture. Proc Natl Acad Sci USA 89:10302-10305

Iguchi A, Ozaki S, Nakamura T, Inoue M, Tanaka Y, Suzuki A, Kawahata H, Sakai K (2011) Effects of acidified seawater on coral calcification and symbiotic algae on the massive coral Porites australiensis. Mar Environ Res 73:32-36

Jassby AD, Platt T (1976) Mathematical formulation of the relationship between photosynthesis and light for phytoplankton. Limnol Oceanogr 21:540-547

Jeffrey SW, Humphrey GF (1975) New spectrophotometric equations for determining chlorophylls $a, b, c_{1}$ and $c_{2}$ in higher plants, algae and natural phytoplankton. Biochem Physiol Pflanzen 167:191-194

Jones RJ, Hoegh-Guldberg O, Larkum AWD, Schreiber U (1998) Temperature-induced bleaching of corals begins with impairment of the $\mathrm{CO}_{2}$ fixation mechanism in zooxanthellae. Plant, Cell Environ 21:1219-1230

Langdon C, Atkinson MJ (2005) Effect of elevated $\mathrm{pCO}_{2}$ on photosynthesis and calcification of corals and interactions with seasonal change in temperature/irradiance and nutrient enrichment. J Geophys Res. doi:10.1029/2004JC002576
Leclercq N, Gattuso J-P, Jaubert J (2002) Primary production, respiration, and calcification of a coral reef mesocosm under increased $\mathrm{CO}_{2}$ partial pressure. Limnol Oceanogr 47:558-564

Leggat W, Badger MR, Yellowlees D (1999) Evidence for an inorganic carbon-concentrating mechanism in the symbiotic dinoflagellate Symbiodinium sp. Plant Physiol 121:1247-1255

Lesser MP (1997) Oxidative stress causes coral bleaching during exposure to elevated temperatures. Coral Reefs 16:187-192

Lesser MP, Weis VM, Patterson MR, Jokiel PL (1994) Effects of morphology and water motion on carbon delivery and productivity in the reef coral, Pocillopora damicornis (Linnaeus): Diffusion barriers, inorganic carbon limitation, and biochemical plasticity. J Exp Mar Biol Ecol 178:153-179

Loya Y, Sakai K, Yamazato K, Nakano Y, Sambali H, van Woesik R (2001) Coral bleaching: the winners and the losers. Ecol Lett 4:122-131

Meehl GA, Arblaster JM, Tebaldi C (2007) Contributions of natural and anthropogenic forcing to changes in temperature extremes over the United States. Geophys Res Lett 34:L19709

Muscatine L, Falkowski PG, Porter JW, Dubinsky Z (1984) Fate of photosynthetic fixed carbon in light-and shade-adapted colonies of the symbiotic coral Stylophora pistillata. Proc R Soc Lond B 222:181-202

Pandolfi JM, Connolly SR, Marshall DJ, Cohen AL (2011) Projecting coral reef futures under global warming and ocean acidification. Science 333:418-422

Platt T, Gallegos CL, Harrison WG (1980) Photoinhibition of photosynthesis in natural assemblages of marine phytoplankton. J Mar Res 38:687-701

Putnam HM, Stat M, Pochon X, Gates RD (2012) Endosymbiotic flexibility associates with environmental sensitivity in scleractinian corals. Proc R Soc B. doi:10.1098/rspb.2012.1454

Quinn GP, Keough MJ (2002) Experimental design and data analysis for biologists. Cambridge University Press, Cambridge

Ragni M, Airs RL, Hennige SJ, Suggett DJ, Warner ME, Geider RJ (2010) PSII photoinhibition and photorepair in Symbiodinium (Pyrrhophyta) differs between thermally tolerant and sensitive phylotypes. Mar Ecol Prog Ser 405:57-70

Raven J (2005) Ocean acidification due to increasing atmospheric carbon dioxide. The Royal Society http://royalsociety.org/ uploadedFiles/Royal_Society_Content/policy/publications/2005/ 9634.pdf

Reynaud S, Leclercq N, Romaine-Lioud S, Ferrier-Pagès C, Jaubert J, Gattuso J-P (2003) Interacting effects of $\mathrm{CO}_{2}$ partial pressure and temperature on photosynthesis and calcification in a scleractinian coral. Global Change Biol 9:1660-1668

Schneider K, Erez J (2006) The effect of carbonate chemistry on calcification and photosynthesis in the hermatypic coral Acropora eurystoma. Limnol Oceanogr 51:1284-1293

Sebens KP, Johnson AS (1991) Effects of water movement on prey capture and distribution of reef corals. Hydrobiologia 226:91-101

Smith DJ, Suggett DJ, Baker NR (2005) Is photoinhibition of zooxanthellae photosynthesis the primary cause of thermal bleaching in corals? Global Change Biol 11:1-11

Stimson J, Kinzie RA (1991) The temporal pattern and rate of release of zooxanthellae from the reef coral Pocillopora damicornis (Linnaeus) under nitrogen-enrichment and control conditions. J Exp Mar Biol Ecol 153:63-74

Suggett DJ, Dong LF, Lawson T, Lawrenz E, Torres L, Smith DJ (2013) Light availability determines susceptibility of reef building corals to ocean acidification. Coral Reefs 32:327-337

van Vuuren DP, Edmonds J, Kainuma M, Riahi K, Tomson A, Hibbard K, Hurtt GC, Kram T, Krey V, Lamarque J-F, Masui T, Meinshausen M, Nakicenovic N, Smith SJ, Rose SK (2011) The representative concentration pathways: an overview. Climatic Change 109:5-31 
Venn AA, Tambutté E, Lotto S, Zoccola D, Allemand D, Tambutté S (2009) Imaging intracellular $\mathrm{pH}$ in a reef coral and symbiotic anemone. Proc Natl Acad Sci USA 106:16574-16579

Wall CB, Edmunds PJ (2013) In situ effects of low pH and elevated $\mathrm{HCO}_{3}{ }^{-}$on juvenile massive Porites spp. in Moorea, French Polynesia. Bio Bull (in press)

Warner ME, Fitt WK, Schmidt GW (1996) The effects of elevated temperature on the photosynthetic efficiency of zooxanthellae in hospite from four different species of reef coral: a novel approach. Plant, Cell Environ 19:291-299

Warner ME, Fitt WK, Schmidt GW (1999) Damage to photosystem II in symbiotic dinoflagellates: A determinant of coral bleaching. Proc Natl Acad Sci USA 96:8012-8807
Warner ME, Lesser MP, Ralph PJ (2010) Chlorophyll fluorescence in reef building corals. In: Suggett DJ, Borowitzka MA, Prášil O (eds) Chlorophyll a fluorescence in aquatic sciences: methods and applications. Developments in Applied Phycology 4:209-222

Weis VM, Smith GJ, Muscatine L (1989) $\mathrm{A} \mathrm{CO}_{2}$ supply mechanism in zooxanthellae cnidarians: role of carbonic anhydrase. Mar Biol 100:195-202

Wilkinson C (ed) (2008) Status of coral reefs of the world: 2008. Global Coral Reef Monitoring Network, Townsville 